\title{
Error Analysis of Fifth-Grade Students of Elementary School in Geometry Problem Solving Based on Newman's Procedure
}

\author{
Meti Widiawati*, Anesa Surya, Siti Istiyati, Sukarno \\ Department of Elementary Teacher Education, Sebelas Maret University, Indonesia
}

Received December 2, 2019; Revised March 27, 2020; Accepted April 5, 2020

Copyright $\odot 2020$ by authors, all rights reserved. Authors agree that this article remains permanently open access under the terms of the Creative Commons Attribution License 4.0 International License

\begin{abstract}
This research aimed to analyze the errors of fifth-grade students in solving the problem-solving questions about geometry. The form of this research is descriptive research with a quantitative approach. The research subjects were 32 students of VB class at Danukusuman Elementary School in the 2018/2019 academic year. The data were analyzed with descriptive and content analyses using the Newman procedure. The technique of data collection used an essay test in the form of story problems about solid geometry (cube and beam). The findings show that the pattern of errors made by the students classically is based on Newman's procedure, namely: (1) reading of $7.3 \%$, (2) comprehension of $35.42 \%$, (3) transformation by $47.92 \%$, (4) process skill of $66.67 \%$, and (5) encoding of $85.42 \%$. Furthermore, from the results of the percentage, error patterns can be categorized in general. The categorization explains the level of children in making a pattern of errors that is described by the number of students in the research subject (32 students). Categories consist of four, which are very low, low, high, and very high. This makes it easy to read the analysis of the number of students who make a pattern of errors. The findings are the preliminary research to determine the pattern of errors in problem-solving based on Newman's procedures and the factors that cause errors in solving the problems in solid geometry (cube and beam).
\end{abstract}

Keywords Geometry, Solid Geometry, Problem Solving, Newman's Procedure

\section{Introduction}

Problem-solving skills are $21^{\text {st }}$-century integrated skills that students need to have [1]. Problem-solving skills involve the ability to think of analyzing, interpreting, reasoning, predicting, evaluating and reflecting with regular, orderly, and complex behavioral patterns to deal with global competition (ASEAN Economy Community) in the $21^{\text {st }}$ century which is based on human resources that are able to collaborate by communicating well, have high order thinking skills (HOTS) skills, and are able to solve various problems [2][3][4]. Students have problem-solving skills if they understand the steps in solving problems in the form of understanding the problem, planning problem solving, implementing the plan, and reviewing because, in essence, problem-solving involves a combination of base knowledge and base skills. The activities of analyzing, linking concepts, arranging planning are the human base skills in solving problems [5]. Problem-solving skills are closely related to the objective of mathematics learning to train students to have the ability to obtain, process, and utilize information in conditions that are always changing, uncertain, and competitive with logical, analytical, systematic, critical, creative, and collaborative ways of thinking related to abstract mathematical objects that begin with an inductive reasoning process from a number of data observations in everyday life in concrete operational stages [6][7][8][9].

The mastery of problem-solving skills in elementary schools is still relatively low. The findings in the Mathematics Teacher Development Centre in several elementary schools in Indonesia revealed that most elementary school students have difficulty in solving problem-solving problems and translating everyday life problems into mathematical models [10]. Besides, the research of S. Hidayah [11] stated that story problems are a basic subject difficult for students, both in Indonesia and in other countries, to master. One of the elementary school materials that contain a lot of problems- solving in the form of story problems is geometry. Students are required to have problem-solving skills related to geometry problems. One way to find out the level of student skills in problem- 
solving is by diagnosing their difficulties. This is in line with White's opinion (2009) [12] that to diagnose the type of students' difficulties can be carried out by analyzing their errors in completing story problems using Newman's error analysis. Newman defines five specific skills about mathematics literacy and numeracy which are essential in the activities of solving mathematical story questions consisting of five stages that students must pass, namely: reading, comprehension, transformation, process skill, and encoding [13][14]. Based on the above description, this research was aimed at analyzing the types of errors and indicators of the causes of errors of fifth-grade students in solving geometry problems based on Newman's procedure. The findings serve as the preliminary research to determine the pattern of students' errors that vary based on the Newman's procedure so that in the future, solutions can be found to minimize the students' errors in answering questions that contain problem-solving.

\section{Methods}

The form of this research is descriptive research with a quantitative approach. The research subjects were 32 students of VB class at Danukusuman Elementary School in the 2018/2019 academic year. The students were assessed using Newman's procedure [15] resulting in various types of students' errors. The technique of data collection used an essay test in the form of story problems about geometry. The types of students' errors in doing problem-solving questions of geometry were scored using the assessment instrument as shown in table 1.

Table 1. Indicators of Student Errors in Problem Solving Based on Newman's Procedure

\begin{tabular}{|c|c|c|}
\hline No & Types of Errors & Indicators \\
\hline A & Reading & A1, A2, A3 \\
\hline B & Comprehension & B1, B2, B3 \\
\hline C & Transformation & CI, C2, C3 \\
\hline D. & Process Skill & D1,D2, D3 \\
\hline E & Encoding & E1, E2, E3 \\
\hline
\end{tabular}

Each type of errors described in table 1 has 3 indicators. Each indicator in each type of error is scored 1. The students get a score of 3 if they make errors in 3 indicators, score 2 for errors in 2 indicators, score 1 for an error in 1 indicator, and score 0 for not making any errors. The criteria of the problem-solving skill test result scoring [16] can be seen in table 2 .

Based on table 2, it is determined that the types of students' errors in solving geometry problems, according to Newman's procedure, are in the high category if the score reaches 7.5 or if they make more than 7 errors of indicators in working on the problems. The data analysis techniques used in this research are descriptive and content analysis.
Table 2. Categorization of the Types of Student Errors in Problem Solving

\begin{tabular}{|c|c|c|}
\hline \multicolumn{2}{|c|}{ Score Interval of the Types of Errors } & Categories \\
\hline $\mathrm{X} \geq \overline{\mathbf{X}}+1 . \mathrm{SB}_{\mathrm{X}}$ & $\mathrm{X} \geq 10$ & Very High \\
\hline$\overline{\mathbf{X}}+1 . \mathrm{SB}_{\mathrm{X}}>\mathrm{X} \geq \overline{\mathbf{X}}$ & $10>\mathrm{X} \geq 7,5$ & High \\
\hline$\overline{\mathbf{X}}>\mathrm{X} \geq \overline{\mathbf{X}}-1 . \mathrm{SB}_{\mathrm{X}}$ & $7.5>\mathrm{X} \geq 5$ & Low \\
\hline $\mathrm{X}<\overline{\mathbf{X}}-1 . \mathrm{SB}_{\mathrm{X}}$ & $\mathrm{X}>5$ & Very Low \\
\hline
\end{tabular}

\section{Result and Discussion}

The Newman procedure is a method that analyzes errors in solving problem. There are 5 stages that must be done by students in solving problem. There are (1) reading, students must be able to represent what they read according to their understanding; (2) comprehension, students know the problem to be solved by showing the idea of the problem; (3) transformation, students are able to choose a plan approach to solving problem; (4) process skill, students choose the exact calculation procedure according to the plan at the transformation level; and (5) encoding, students can write the answers correctly and right after the checking process. Furthermore, the results and discussion of this research consist of 5 types of errors based on Newman's procedure, as follows:

\subsection{Five Types of Errors Based on Newman's Procedure: Reading Error}

Reading errors consist of 3 indicators; they are: (1) The students are not able to read or recognize keywords and symbols in the questions (A1); (2) They are not able to interpret the problems of the questions (A2); and (3) They are not able to process problem solving (A3). The results of the students' reading errors can be seen in figure 1 .

Figure 1 shows the results of the students' reading error analysis in solving geometry problems. Based on figure 1, it shows that there are no students who made A1 errors, it proves that students mastered reading or recognize keywords and symbols in the questions. Then, 1 student who made A2 errors and 8 students who made A3 errors. The highest error is that students can't process problem-solving (A3) resulting from that students are not able to read or recognize keywords and symbols in the questions (A1) and they are not able to interpret the problems of the questions (A2). This is following Ismail $\mathrm{Hj}$ Raduan's research [17] explaining that when solving problems, students will pass two phases, namely the interpretation of the language mathematics and the calculation process. The first phase involves interpreting language in the form of numbers and equations. The first phase shows the linkages with indicators of reading errors, which are usually problems by students in understanding the language, sentences, and words they read. 


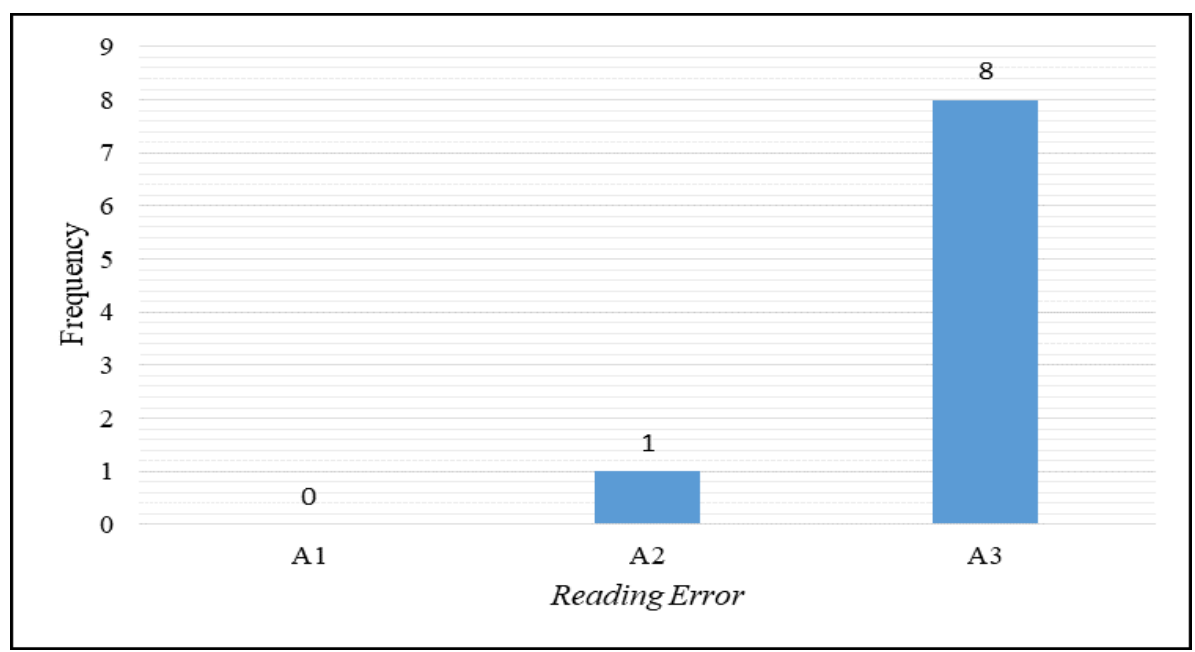

Figure 1. Results of Reading Error Analysis (total students)

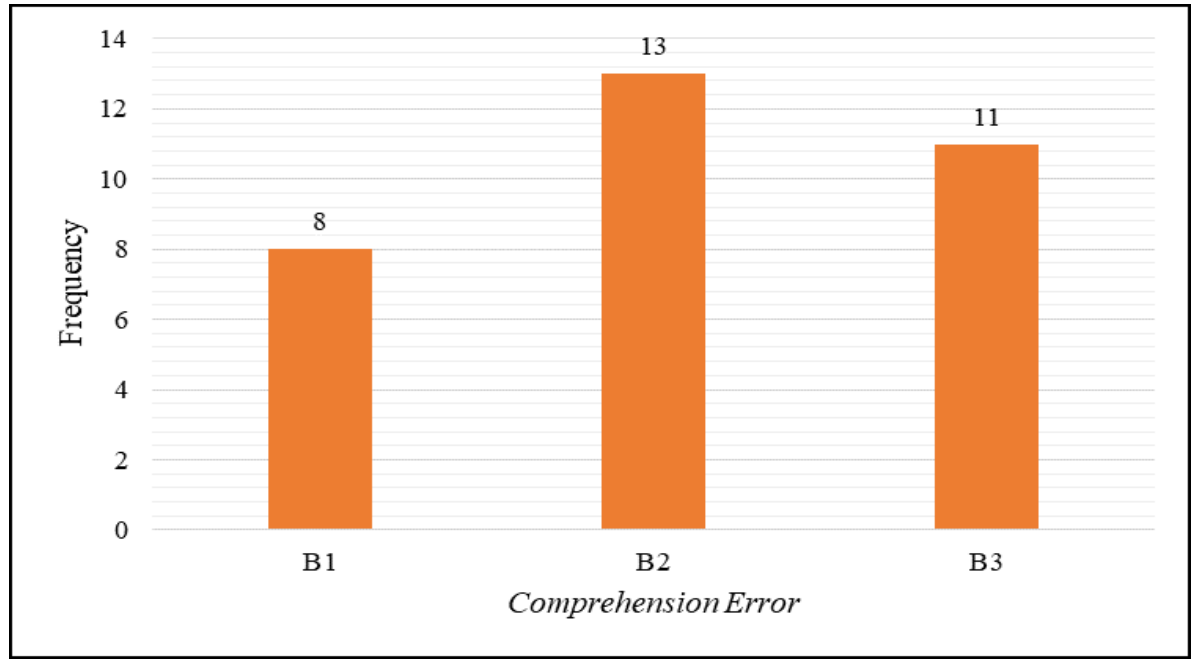

Figure 2. Results of Comprehension Error Analysis (total students)

\subsection{Five Types of Errors Based on Newman's Procedure: Comprehension Error}

Comprehension errors consist of 3 indicators; they are: (1) The students are unable to analyze the information about the problem (B1); (2) They do not write information on problems with mathematical sentences (B2); and (3) They are not able to analyse what is asked in the question (B3). The results of students' comprehension errors can be seen in figure 2.

Figure 2 shows the results of the students' comprehension error analysis in solving geometry problems. Based on figure 2, it shows that there are 8 of 32 students who made B1 errors, 13 students who made A2 errors and 11 students who made B3 errors. The highest error is the B2 that students do not write information on problems with mathematical sentences, as in the study P. Rahayuningsih and A. Qohar [18] that comprehension error indicated when the students don't know or don't write the correct information in the question. The research of Parmjit et al.,[19] also shows that comprehension errors occur when students can read questions but fail to understand the requirements, causing them to be wrong or fail to try to solve the problem.

\subsection{Five Types of Errors Based on Newman's Procedure: Transformation Error}

Transformation errors consist of 3 indicators; they are: (1) The students are not able to make mathematical models of information obtained (C1); (2) They do not know the formula that will be used to solve the problem (C2); and (3) They are not able to present problem-solving strategies (C3). The results of students' transformation errors can be seen in figure 3. 


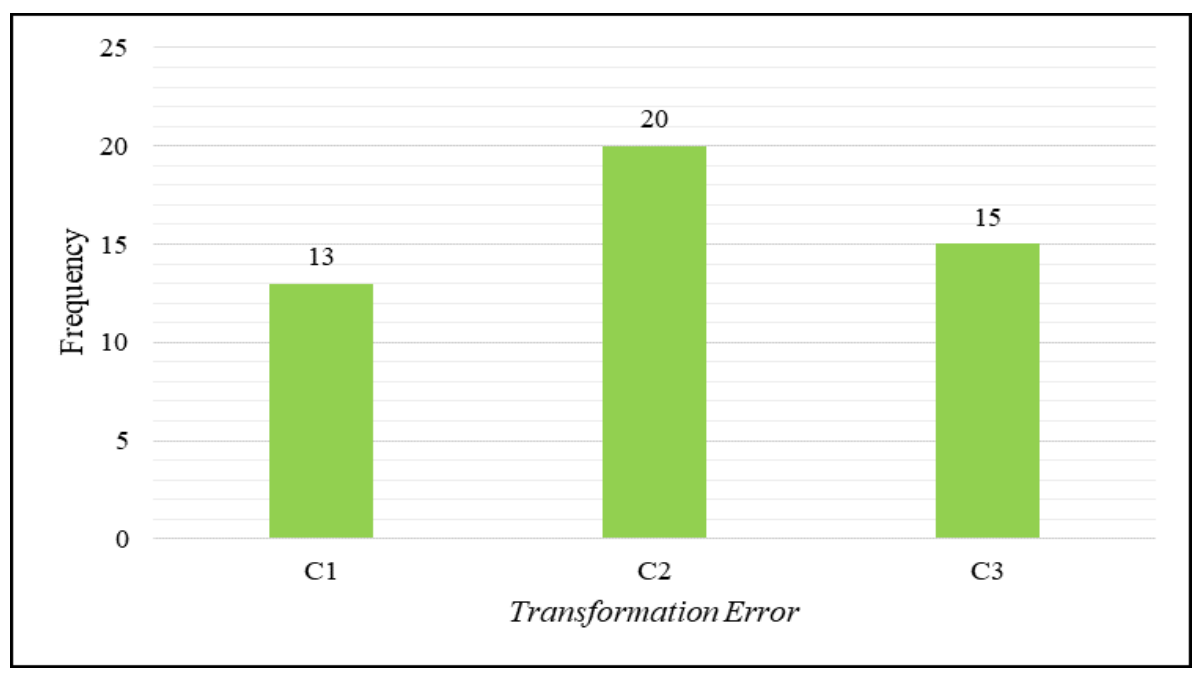

Figure 3. Results of Transformation Error Analysis (total students)

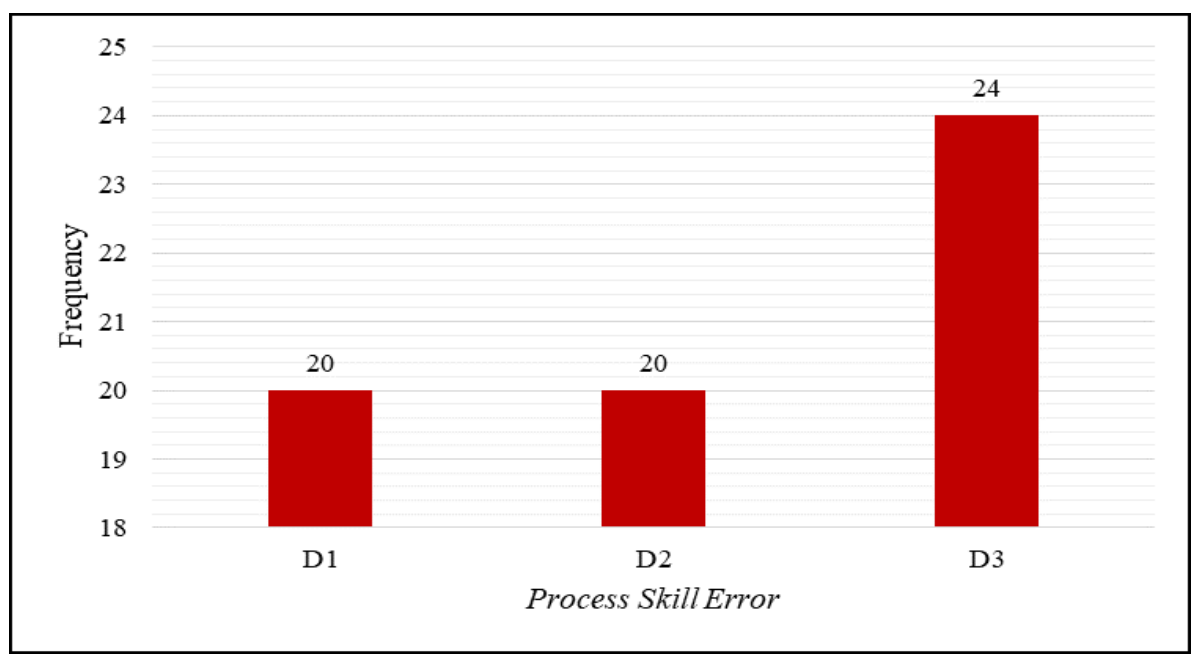

Figure 4. Results of Process Skill Error Analysis (total students)

Figure 3 shows the results of the students' transformation error analysis in solving geometry problems. Based on figure 3, it shows that there are 13 of 32 students who made $\mathrm{C} 1$ errors, 20 students who made $\mathrm{C} 2$ errors and 15 students who made $\mathrm{C} 3$ errors. The $\mathrm{C} 3$ error indicator is the highest error made by students in transformation error analysis which students do not know the formula that will be used to solve the problem. That errors explained that is when the students have understood well the question but failed to identify the appropriate mathematical operations or sequence of operations as a solution to solve the problem [16].

\subsection{Five Types of Errors Based on Newman's Procedure: Process Skill Error}

Process skill errors consist of 3 indicators; they are: (1) The students are not able to accept the sequence of strategies or steps for systematic problem solving (D1); (2)
They are not able to translate the suitability between results and processes (D2); and (3) They are not able to answer questions according to the sequence of problem-solving strategies (D3). The results of the students' process skill errors can be seen in figure 4.

Figure 4 shows the results of the student process skill error analysis in solving geometry problems. Based on figure 4 , it shows that there are 20 of 32 students who made D1 errors, 20 students who made D2 errors, and 24 students who made D3 errors. Jha (2012) in D. Rahmawati and L. Permata [20] explained that the process skill error is that students can identify the appropriate operation or a series of operations, but do not know the steps needed to carry out the operation perfectly. This is according to figure 4 that states that the highest error in the skill error process is in D3 which students are not able to answer questions according to the sequence of problem-solving strategies. 


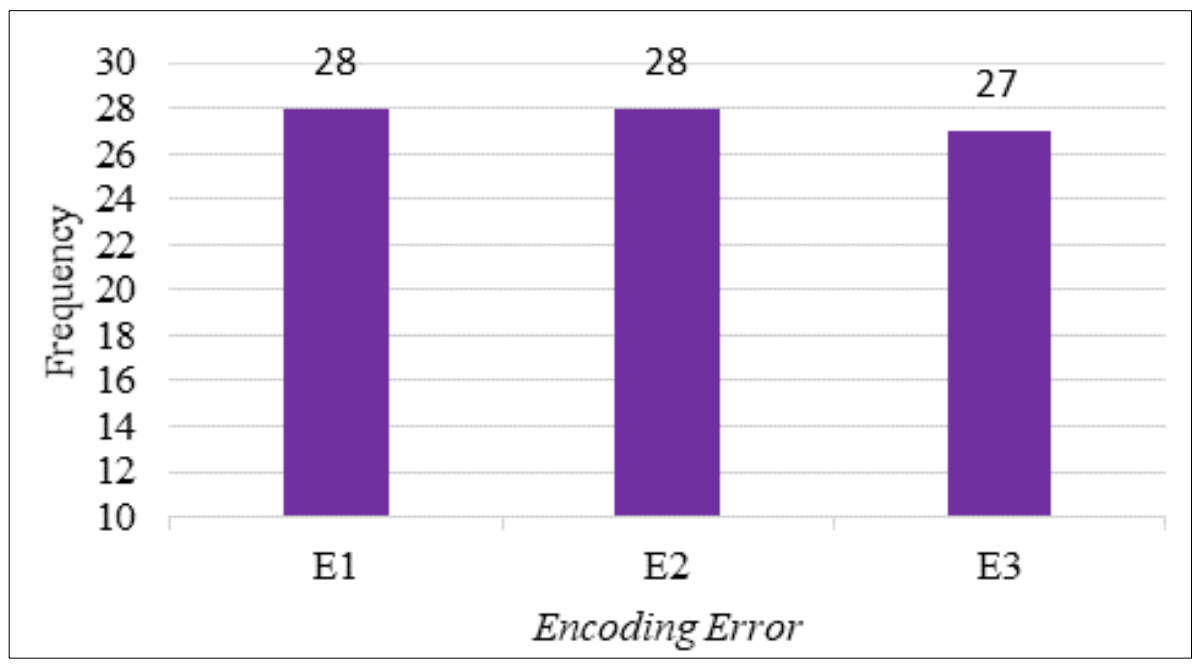

Figure 5. Results of Encoding Error Analysis (total students)

\subsection{Five Types of Errors Based on Newman's Procedure: Encoding Error}

Encoding errors consist of 3 indicators; they are: (1) The students are not able to find the final results of the problem based on the procedure or steps used (E1); (2) They do not write conclusions from the problem correctly (E2); and (3) They do not write down the length unit completeness based on the information obtained (E3). The results of students' encoding errors can be seen in figure 5 .

Figure 5 shows the results of the student process skill error analysis in solving geometry problems. Based on figure 5, it shows that there are 28 of 32 students who made E1 errors, 27 students who made E2 errors and 27 students who made E3 errors. The finding of E. Kurniawan [21] said that encoding errors occur when students are unable to find the final results according to the procedure. They are unable to show the final results of problem-solving and to write the final answer according to the conclusions referred to in the problem.

Based on the results of the analysis of the types of students' errors based on Newman's procedure above, it shows that the types of errors made by students in solving problems related to geometry material are varied. This is backed by the research of Sughesti et al. [22], which concluded that students made errors with different numbers in almost all subjects.

\subsection{Percentage of Student Errors in Each Aspect Based on Newman's Procedure}

Figure 6 shows that the results of the data display of encoding errors are Newman's procedure types of errors that have the highest percentage while reading errors are the lowest percentage of procedural errors. The details are reading error of $7.3 \%$, comprehension error of $35.42 \%$, transformation error of $47.92 \%$, process skill error of $66.67 \%$, and encoding error of $85.42 \%$. The research conducted by K. Zamzam and F. Patricia [23] showed the results of their study that the errors are often done in the stage of transformation and process skills. The error occurs because students do not understand the procedure that will be used to solve the problem, because the material is not well understood. On one hand, the research conducted by A. Fatahillah et al. [24] showed that the highest percentage of errors was the comprehension error of $69.24 \%$, while the lowest percentage of errors was the reading error of $23.12 \%$. Thus, it can be said that the types of students' errors based on Newman's procedures are varied. The categorization of the types of students' errors based on Newman's procedure is seen in figure 7 below. 


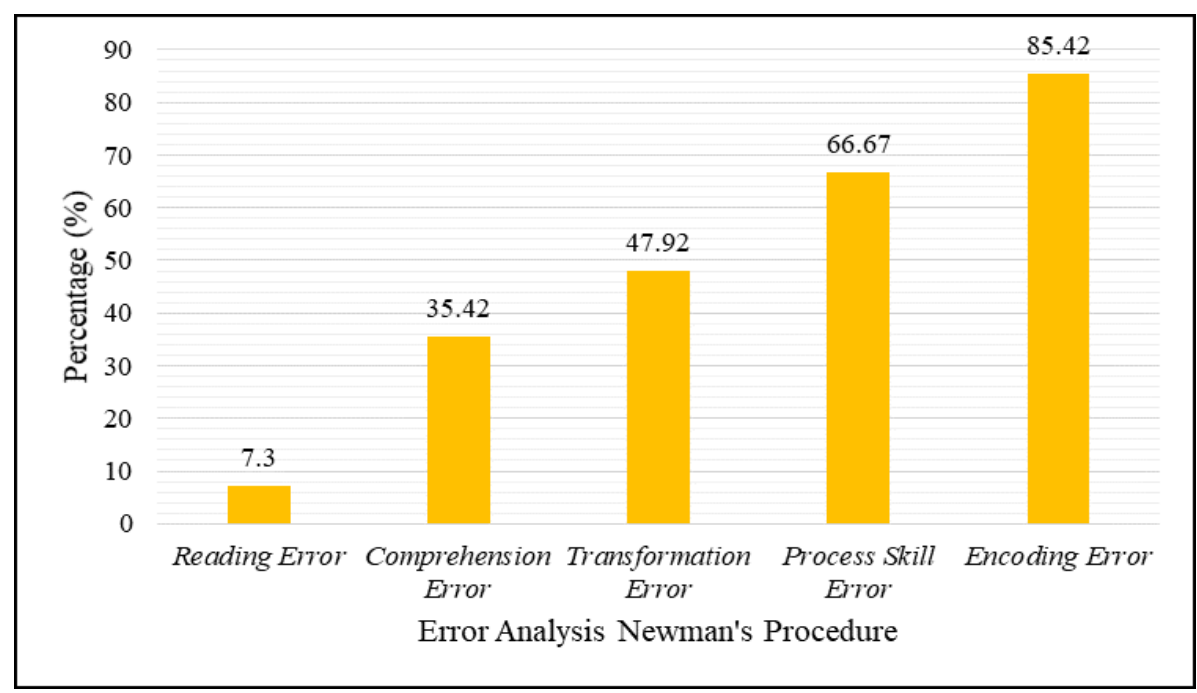

Figure 6. Percentage of Types of Errors in Newman's Procedure

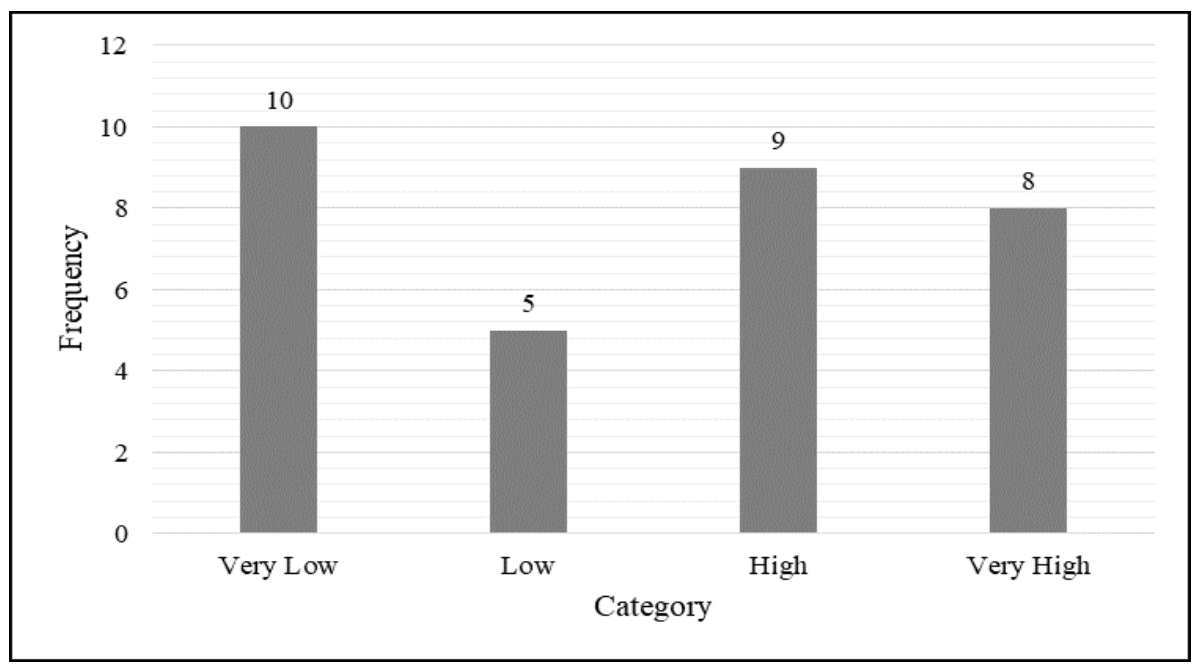

Figure 7. Categorization of Types of Errors in Newman's Procedure (total students)

\subsection{The Categorization of the Types of Student Errors Based on Newman's Procedure}

Figure 7 describes the categorization of Newman's types of errors globally. There are four categories to find out the number of students based on the error grouping in Newman's procedure. The picture above shows that there are 10 students belonging to the very low category or making less than 5 errors, 5 students classified as the low category or making 5-7 errors, 9 students classified as the high category or making 8-9 errors, and 8 students still classified as the very high category or making more than 10 errors. The types of errors the students made in solving problems related to the geometry material are varied. This can be explained in figure 7 in the form of the percentage of students' errors in each aspect based on Newman's procedure, as follows. Moreover, the categorization in Figure 7 shows that using of the Newman's procedure can explain error analysis the students to answer the detail of the questions and clearly, this can be seen from the graph showing that the categories of difficulties in students variated. This argument is reinforced by the journal [25] which concludes that the inclusion of Newman's Error Analysis (NEA) was a powerful classroom diagnostic assessment and teaching tool for assessing, analyzing and catering for a student experiencing difficulties with mathematical word problems.

\section{Conclusions}

Based on the results of the above research, it can be concluded that as stated in the research of Tambychik et.al, [26] Polya (1981) that problem solving is a process that starts from students faced with problems and ends when the problem is resolved. It is continuous with the analysis of types of errors based on Newman, which is a series of error patterns from the beginning to the end of the students' solving problems. Students' errors in solving problems vary from reading errors, comprehension errors, 
transformation errors, process skill errors, and encoding errors. Besides, the research conducted by RC Chusnul et al. [27] stated that error analysis based on Newman's procedure can help students solve problems well because they have already known and understood their mistakes made before.

\section{Acknowledgments}

The authors would like to thank the Sebelas Maret University that supported and funded this research.

\section{REFERENCES}

[1] J. Levin-Goldberg, Teaching Generation TechX with the 4Cs : Using Technology to Integrate 21st Century Skills. 1, 9-66, (2012).

[2] T. K. Ngang, S. Nair, and B. Prachak, J. Procedia - Soc. Behav. Sci., 16, 3760-3764 (2014).

[3] H. Ulya, J. Konseling GUSJIGANG, 2(1), 90-96 (2016).

[4] M. Syah, Psikologi Pendidikan (Remaja Rosdakarya, Bandung, 2014).

[5] E. A. Khairunnisa, Riyadi, and H. Mahfud, J. Soc. Humanity. Educ. Stud., 1(1), 225-231 (2018).

[6] National Council of Teacher Mathematic (NCTM). 2000.

[7] F. Shadiq, Pembelajaran Matematika; Cara Meningkatkan Kemampuan Berpikir Siswa (Graha Ilmu, Yogyakarta, 2014).

[8] Departemen Pendidikan Nasional (Depdiknas), 2006.

[9] Heruman, Model Pembelajaran Matematika di Sekolah Dasar (Remaja Rosdakarya Offset, Bandung, 2014).

[10] S. W. Danoebroto, "Improving Problem Solving Skill Using the PMRI, pp. 73-87 (2008).

[11] S. Hidayah, Analisis Kesalahan Siswa Dalam Menyelesaikan Soal Cerita SPLDV berdasarkan Langkah Penyelesaian Polya, 1, 182-190 (2016).

[12] A. M. Putri and M. T. Budiarto, J. Mathedunesa, J. Ilm. Pendidik. Mat., 2(6) (2017).

[13] S. R. Amalia, J. Aksioma, 8(1), 17-30 (2017).

[14] I. Karnasih, Analisis Kesalahan Newman pada Soal Cerita Matematis, 8, 37-51 (2015).

[15] A. Newman, Newman Promt. (1977).

[16] D. Mardapi, Pengukuran, Penilaian dan Evaluasi Pendidikan (2017).

[17] I. Hj, Error analysis and the corresponding cognitive activities committed by year five primary students in solving mathematical word problems, 2(2), 836-3838 (2010).
[18] P. Rahayuningsih and A. Qohar, J. Pendidik. Mat. dan Sains, 2(2), 109-116 (2014).

[19] P. Singh, A. Abdul, and T. Sian, The Newman Procedure for Analyzing Primary Four Pupils Errors on Written Mathematical Tasks : A Malaysian Perspective, 8(5), 264271 (2010).

[20] D. Rahmawati and L. D. Permata, Soal Cerita Program Linear Dengan Prosedur Newman, 5(2), 173-185 (2018).

[21] E. Kurniawan, J.Ekuivalen, pp. 26-31.

[22] M. M. Sughesti, G. Muhsetyo, and H. Susanto, Jenis Kesalahan Siswa dalam Menyelesaikan Soal Cerita Berdasarkan Prosedur Newman, 2016.

[23] K. F. Zamzam and F. A. Patricia, Error Analysis of Newman to Solve the Geometry Problem in Terms of Cognitive Style, 160, 24-27 (2018).

[24] A. Fatahillah, Y. F. N. T Wati, and Susanto, J. Kadikma, 8(1), 40-51 (2017).

[25] A. L. White, J. Sci. Math. Educ. Southeast Asia, 33(2), 129$148(2010$.

[26] T. Tambychik, T. Subahan, and M. Meerah, Students' Difficulties in Mathematics Problem-Solving: What do they say ?, 8(5), 142-151 (2010).

[27] R. C. C and D. R. S, "Errors analysis of problem-solving using the Newman stage after applying cooperative learning of TTW type Errors Analysis of Problem Solving Using The Newman Stage After Applying Cooperative Learning of TTW Type 020028 (2017). 